\title{
THE HUMAN CAPITAL THEORY AS A METHODOLOGICAL FOUNDATION OF CONTINUOUS VOCATIONAL EDUCATION
}

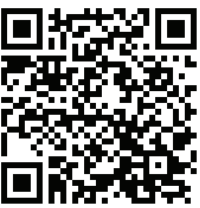

To cite this article:

\author{
Nellia Nychkalo, Dr. Sc., Prof. \\ Academician-Secretary, Department \\ of Professional and Adult Education, \\ National Academy of Educational Sciences of Ukraine, \\ Kyiv, Ukraine \\ napn24@gmail.com \\ https://orcid.org/0000-0002-5989-5684
}

Nychkalo, N. (2018). The human capital theory as a methodological foundation of continuous vocational education. Education: Modern Discourses, 1, 107-117.

https://doi.org/10.32405/2617-3107-2018-1-10

\begin{abstract}
The human capital theory is considered based on the interdisciplinary approach from three perspectives - individual, microeconomic and macroeconomic. The contemporary approaches to the implementation of the state policy on vocational education are analysed. It is given a comprehensive overview of the main vocational education mission - to provide preparation of the younger generation to employment and different adult population categories with continuous professional development. It requires forecasting - technological, demographic, economic and political (according to D. Bell). It is considered the problems of self-actualization and professional identity treated as a basis for human capital development. It has been proven that a methodological foundation of a theoretical analysis of personality self-actualization in professional life is formed based on the subjective and pragmatic, personality developing and acmeological approaches. It is stressed the importance of using the occupational prestige monitoring results (based on Traiman's International Occupational Prestige Scale) in scientifically substantiated forecast of labour market changes and forward-looking modernization of the vocational training system. An emphasis is placed on the importance of the Ukrainian scholars' works (S. Goncharenko, I. Ziaziun, G. Kostiuk, V. Kremen, S. Maksymenko, V. Moliako, D. D. Thorzhevskiy) for implementation of the forward-looking approach in vocational training modernization. It is made the original recommendations for the state policy on this issue at the nationwide, regional, field and academic research levels. Some attention is given to the European strategy "Europe 2020" that is of critically importance not only for the UE Member-States but also for candidate countries.
\end{abstract}

Key words: personality; professional development; professional self-actualization; professionalization; career guidance; labour market.

\section{INTRODUCTION. PROBLEM STATEMENT}

In the late $20^{\text {th }}$ - early $21^{\text {st }}$ century the concept of continuing education has become of international importance. The search for ways of its realization in different pedagogical systems is being carried out across the globe. In the USA and Canada, Japan and China, 
Great Britain and Germany, Poland and Finland there have been elaborated strategic programs, special laws have been passed and target financing of continuing education for different population categories is provided.

The objective necessity of closer attention to continuing education problems arises from dynamic changes under the conditions of information and technological society, market requirements to specialists' competency, their rapid professional adaptation, the need for constant learning, re-skilling and skills upgrading. Thus, it is no surprise that such critically important issues have become a concern of the International Labour Organization, the UNESCO Institute for Lifelong Learning in Hamburg, the International Council for Adult Education, the International Association for the Education of Adults, the European Centre for the Development of Vocational Training, the Institute for International Cooperation, the German Adult Education Association and other organizations.

International documents on education problems have for a long time substantiated a considerable attention given by governmental authorities and progressive communities from many countries of the world to implementation of the European Commission's Memorandum on Lifelong Learning (2000) as well as the UNESCO's program "Education for All" (2002).

The system of vocational education is one of the most important and complicated in society's functioning. It performs many functions, in particular the following: social, economic, culture-creating, educational, cognitive etc. They are closely interrelated and are fulfilled in a systemic interaction of educational institutions of different types and ownership forms, enterprises and organizations of all the sectors of economy, social partners, non-governmental organizations, community associations, public and administrative authorities.

Experience of many years certifies the fact that this system plays an extremely important role in national security protection. Facilitation of innovation-driven development of national continuing vocational education systems is a prioritized goal of many world advanced countries' state policy. Moreover, this is no accident, as such an approach creates a stable foundation and at the same time is key to real growth of human capital in all its respects.

\section{MAIN RESULTS}

\section{Human Capital as an Economic and Pedagogical Category}

Under the conditions of a rapid development of globalization and integration processes the theory of human capital is becoming increasingly important. It was theoretically substantiated and introduced into scientific use on the cusp of the 50s and 60 s of the $20^{\text {th }}$ century. The author of the theory was Gary Stanley Becker, the outstanding American economist and the professor of Columbia and Chicago Universities. He "applied theoretical economics methodology to a description of human behaviour aspects that used to be the scope of sociology and demography only". In the scientific papers "Human Capital" (1964) and "A Treatise on the Family" (1981) the professor put forth and substantiated the rational economic choice theory on the basis of individual human interests that determine a considerable part of human activities, even not economic by nature such as starting a family. According to the theory, expenditures on education are considered investments in human capital. It is the human capital theory 
introduced by G. S. Becker who became the Nobel Prize laureate in 1922 that underlies strategies of vocational education systems development in advanced countries of the world" (Shynkaruk, 2002: p. 179).

In view of this, the name of Theodore William Schultz - the representative of the Chicago School of Political Economy, the director of the National Bureau of Economic Research in the USA (1949-1967), the author of research papers on developing countries' economic problems, labour force formation and the economic role of education, the Nobel Prize winner in 1979 (together with Arthur Lewis), should not go unmentioned.

The scholars have demonstrated that the human being with their creativity serves as the driving force behind vigorous activities, continuously flowing creative juices, the search for new approaches over the course of their lifecycle. In Schultz's terms, education, a professional qualification, developed skills and health are treated as the concepts of particular economic value related to human capital. Other economists have introduced some new aspects of the theory, developing it respectively. It is worth mentioning that the notion of "schooling and professional training" as an investment was fist substantiated by I. R. Welsh.

Scholars from the following three perspectives consider the concept of "human capital":

- The fist level - individual: human capital refers to knowledge and skills gained by a person during the course of study, professional training, and practical experience using their natural abilities and thanks to which they are able to deliver productive services of value to other people.

- The second level - microeconomic: human capital is composed of an aggregate qualification and professional abilities of all the workers of an enterprise as well as its achievements in an effective labour management and personnel development.

- The third level - macroeconomic: human capital is comprised of accumulated contributions in such fields as education, professional training and retraining, occupational guidance, consultation, employment assistance services and is a considerable part of countries' national wealth; it is called national human capital (Nychkalo, 2012: p. 28-29).

In the process of diversified business activities a person carries out a great number of different functions in accordance with the human capital theory. The key ones lie in the following: a) the use of existing means of production; b) substantiation of new ideas and theories, development of modern tools and technologies; c) substantiation and realization of ways of its implementation in different fields of human activities, social institutions and various sectors of economy. The above listed functions are dynamically expanding, tightly interconnected and renewed during different historical periods.

It should be also emphasized a paramount importance of the human capital theory under the modern social and economic conditions with quite urgent questions of rational employment provision to different social classes and effective labour market operation. Analysing this aspect, it is reasonable to refer to the philosophic and pedagogical ideas substantiated by V. Kremen "a transformation of the humanity in general and our country in particular from industrial manufacturing to scientific and information technologies and consequently formation of the knowledge society are top priorities of any society objectively determining science as a field ensuring production of new knowledge and education and making them available both to the entire society and each individual" (Kremen, 2010: p. 569). The scholar argues that an important creative component of the new world order is the dependence of a country's development rate and international 
status on the level of human capital. Quantitative characteristics of human capital include not just the number of high school, college or university graduates, but also the number of specialists employed in the main branches of industry, transportation, communications etc. and what is more important - the number of researchers in the main spheres of scientific knowledge production. Therefore, human capital is an integrative indicator determining a country's internal potential for production and application of knowledge in its industrial and social development.

It is well known that the product of an education system is a concrete individual prepared for an active professional engagement in different branches of the primary, secondary or tertiary economic sectors. This leads us to the fact that human capital with its spiritual, ethical and moral, professional qualities serves as a key factor determining every country's future. The $88^{\text {th }}$ session of the International Labour Organization's General Conference in 2000 was specifically devoted to the above-mentioned problem. The adopted conclusion on human resources development and personnel training stipulates the requirement for vocational qualification systems to be of a tripartite nature and to provide access of different worker groups and any individuals willing to study. It has to cover both public and private educational institutions and be subject to constant updating enabling the chance to start or finish training within an education and staff training system during the entire professional career (Nychkalo, 2012: p. 30).

\section{State Policy on Vocational Education}

The term "state education policy" or "state policy on education" was first introduced into scientific discourse in the 60s-70s of the past century. There are various definitions of the term "education policy", "state education policy" in Ukraine (V. Andruschenko, L. Huberkyj, V. Kremen, M. Mykhalchenko, V. Ognevyuk, M. Popovych, Yu. Schemschuchenko). It is worth noting that there is no substantial difference in their interpretation with just some additions and specifications. Education as the object of education policy is considered to be "the common good, an intellectual and material resource for society and the system of education institutions". The type of education policy is determined by the character of social, economic and political relationships in society, elite quality, dominant political culture, national education traditions etc" (Kremen (ed.), 2008: p. 623).

According to the definition by V. Halperin and V. Saveliev Ukraine is characterized by the transitional education policy type. Its essence is determined by specificity of postcommunism systemic transformations, contradictions in formation of public policy on administration and management of education, its social status improvement and strengthening in the world and European education area. The state acts as a key education policy agent and interacting with the public, it raises the possibility of making social choices on education matters. The state education policy is a response to societal needs, requirements, actions or inactions of other education policy agents, a relatively stable and result-oriented official focus of the government and its subordinate organizations on education system management (Kremen (ed.), 2008: p. 623). The same is true for technical and vocational education as a key aspect of the state education policy.

There is also a number of other documents of strategic importance that reflect the state's orientation towards qualified workers' training such as the Edict of the President of Ukraine "The main reforming directions of vocational education in Ukraine" of May 8, 1996, the Act of Ukraine "On Vocational Education" of February 10, 1998 (Chyzhevskyi, Holovinov, 
Krasniakov, Shevchenko, 2013). The National Doctrine of Education Development (2002) outlines the perspective objectives of making qualitative training in vocational and training schools equally accessible (II Vseukrainskyi zizd pratsivnykiv osvity).

It is no exaggeration to conclude that the concepts of vocational education development elaborated by the scholars of the NAES of Ukraine were taken into account in the process of enacting legislation and preparation of academic documents on production personnel training. Here we are referring to "the Concept of vocational educational development in Ukraine" that was approved by the Ministry of Education and Science of Ukraine and the NAES on the July 5, 2004 (Nychkalo, 2004: p. 522-526).

"Vocational education for needs of a person, economy, society" which is the section of "The National Report on the State and Prospects of Education Development in Ukraine" outlines the perspective directions of vocational education modernization in the following aspects: legislation; state order formation and implementation; improvement of VET content; expansion of cooperation with employers; vocational education management; raising the prestige of working professions in society and information support of VET together with the introduction of innovative learning technologies; on-the-job vocational training; improvement of pedagogical personnel quality and methodological, financial and logistical support of VET" (Kremen (ed.), 2016: p. 90-91).

The section "Adult Education - as an integral part of lifelong learning" gives a complex overview of the priorities of adult education development in Ukraine and formulates the proposals on legislative regulation and an integral approach to adult education" (Kremen (ed.), 2016: p. 126-137).

Vocational education is meant to undertake an extremely important mission of preparation of the younger generation to employment. Considering this point, let us refer to the idea substantiated by the prominent Ukraine economists A. Halchynskyi. From his perspective, "the formation of the individual by labour is not an act happening in the blink of an eye that has been taking place since the year dot. In fact, it is a permanent process that is constantly developing determining the content of the entire human history. Labour used to and continues to create the individual, it forms our personality, develops the wealth of our social nature and pure biological personification. The systemic unity of social and natural (material) components is formed through the creative function of labour" (Kremen (ed.), 2016: p. 88).

In our opinion, stifling of the vocational education sector leads to reduction in human capital effectiveness.

Implementation of the state policy on production personnel training has to be based on social forecasting. The famous American sociologist and philosopher D. Bell has reached the conclusion that "it is made possible where there are repeatable things and order (which happens rarely) or where there are established tendencies directions of which (if not a precise trajectory) can be identified with the help of statistic time series or formulated in the form of historical trends" (Kremen (ed.), 2002: p. 420).

There exist various forecasting directions: technological, demographic, economic and political (according to Bell). In this context the concept of the post-industrial society, on the basis of which the following five components have been singled out seems to be actual:

- In the economic sector: transformation from manufacturing goods to expansion of the service sector;

- In the occupational structure: domination of professional and technological classes. 
- The axial principle of society: the central role of theoretical knowledge as a source of innovations and policy formation.

- Commitment to the future: a special role of technologies and technological evaluations.

- Making decisions: the creation of the new "intellectual technology" (Nychkalo, 2016: p. 426).

The value of the ideas introduced by the scholar-anticipator lies in the fact that "the main source of structural changes in society, innovations implementation, correlation of theory and technologies and state policy changes are changes in the knowledge type: exponential growth and science branching, appearance of the new intellectual technology, systemic research practice which is possible due to the budgets of "Research and development" organizations and at the top of that codification of theoretical knowledge" (Kremen (ed), 2002: p. 431).

The proposed approaches are connected with prediction and forecasting the results of which are reasonable to use as the rationale behind the state education policy.

\section{Self-actualization and Individual Professional Growth as a Basis of Human Capital Development}

It is commonly known that most researchers of the psychodynamic approach tend to treat self-actualization as the process of individual improvement, overcoming the inferiority complex, defence mechanisms and commitment to personal integrity and maturity. It is a scientifically substantiated fact that in the modern psychoanalysis uniqueness and integrity of each person seeking self-maximation and maturity are stressed. In A. Adler's terms, self-actualization is the ultimate goal in human life complete personal self-fulfilment that is formation of the one and only, integral personality. Development of any individual is a unique and specific process lasting for the whole life (Karamushka \& Tkalych, 2009: p. 15-16).

In recent times there has been an increased focus on the ideas of personal growth, self-perfection and pursuance of self-advancement. These concepts were fist substantiated in the works by scholars who were representatives of the psychodynamic approach. Eventually, these ideas evolved in humanistic psychology. However, it is worth noting that the latter approach interprets the concept of self-actualization from a more positive perspective. It is defined not as overcoming of some inconsistencies and drawbacks in one's personality as it is the case with the psychodynamic approach, but as an orientation to or a focus on growth and development using positive sides of personality" (Karamushka, Tkalych, 2009: p. 19). According to this, every individual in different periods of their life has to master the skill to objectively assess their potential and based on awareness of one's strong points to take further steps forward, be able to see and take stock of their strengths and weaknesses no matter how difficult it can be and determine ways (or mechanisms) of addressing them. It will certainly be beneficial for self-actualization.

Scholars researching humanistic psychology issues define self-actualization as an innate motivation tendency peculiar to every individual that just requires appropriate conditions for its development (Karamushka \& Tkalych, 2009: p. 19). Arrangement of such conditions in a family, at pre-school institutions, primary, secondary and high school, vocational and technical institutions as well as at universities and on the job is an extremely complicated task for parents, educators, psychologies and regulators at different levels. Of course, "appropriate conditions for development" is not an abstract 
category. It is quite concrete, as it requires taking into account psychophysiological constitution of a pre-schooler, students studying at different stages at school as well as young people who have consciously or unconsciously made a career choice. Apart from psychophysiological characteristics, it is necessary to examine ambitions and social environment where they are formed.

Let us refer to the famous concept of self-actualization as a prerequisite of human livelihood at the existential level by A. Maslow. The creator and leader of humanistic psychology opened new prospects for psychological understanding of the individual in the second half of the 20 century (Maslou, 1999). A. Maslow developed the selfactualization theory within the framework of the following three perspectives: selfactualizing personalities; peak experience of transcendental values; self-actualization as a development process.

It seems to be reasonable to refer to the self-actualization theory set forth by $\mathrm{K}$. Rogers. In his terms, self-actualization is a motivating self-protection and selfdevelopment tendency that presupposes manifestation of the best qualities biologically predetermined in humans. Figuratively saying, self-actualization is the main driving force behind human livelihood reflected in the desire to deepen, become independent, develop and mature (Kremen, 2015: p. 20). G. Olport considers self-actualization as an active, sequential and continuous process of personality formation. He stresses that during its course individuals take responsibility for their life quality.

The following well-known approaches form a methodological foundation of a theoretical analysis of personality self-actualization in professional life: subjective and pragmatic, personality developing and acmeological. Without downplaying their importance and value a noteworthy detail is that they are tightly interconnected complementing one another. Let us refer to at least some research findings within the framework of the acmeological approach, as the problem of personality self-actualization in professional life has been the most widely investigated by its representatives. It is well known that in acmeology individual professional development is treated as the process of personal enhancement in a general sense. It is mostly oriented towards a high level of professionalism and professional achievements fostered through education and self-development, professional activities and interaction at different stages of human livelihood (Karamushka \& Tkalych, 2009: p. 37).

Research findings on the occupational prestige problem as a psychological indicator of a labour market model present a considerable scientific interest (M. Naidonov). Based on Traiman's International Occupational Prestige Scale and the usage of unified methodological foundations for elaboration of the Ukrainian prestige standard the scholar has carried out the analysis of occupational prestige as a subjective and objective psychological mechanism of labour market and professional world self-regulation. It was revealed some changes in the mechanism of collective consciousness alteration under the conditions of social and political transformations. It is worth mentioning that the rationale behind keeping track of occupational prestige dynamics is the fact of prestige being the factor of workforce structuring. Making allowance for the research results in career-guidance of different population categories can be an efficient instrument of overcoming negative trends in the Ukrainian labour market and elimination of current inconsistencies between requirements to workforce competitiveness and imbalance in the professional training system, especially of high-qualified workers (Ball, Zlyvkov, Kopylov ta in., 2014: p. 77). 
Such monitoring results should be used as a basis for scientifically substantiated prediction of labour market changes and forward looking modernization of the vocational training system. In this respect it has to be noticed that there have to be considered different systems of vocational training (at vocational schools, higher technical institutes, vocational training systems, on the job training, centres of employment agencies), not just the only one where the unemployed acquire another trade, improve and retrain. Each of these systems is specific depending on its aim and objectives, students and participants' age and psychophysiological peculiarities, their social and professional background experience. Hence, each of such systems has its didactic peculiarities.

At the beginning of the $21^{\text {st }}$ century the ideas of the outstanding Ukrainian psychologist G. Kostiuk on students' employment preparation, polytechnic and professional education are taking on greater relevance. In his opinion "secondary school students' on-the-job training has to become an instrument of employment preparation. It has to be realized on a wide general education and polytechnic basic. The main improvement direction of students' employment preparation is determined by its combination with grasping of the elements of science, the overall presence of an intellectual component in their on-the-job training and work, nurturing the qualities needed for them as active participants in the technological progress" (Kostyuk, 1988: p. 163).

The scientific legacy of D. Thorzhevskiy also shouldn't go unmentioned. His works on labour training and students' professional preparation still hold true today. It quite an interesting fact that together with his mentees (A. Vykhrusch and V. Kukharskiy) the scholar published the monograph "Labour polytechnic school: myths and reality" (1917-1941). Unfortunately, we have to conclude that in the current climate of Ukraine being independent for 27 years we still have plenty of dubious and false myths about such problems.

Over more than the last two decades the scholars of the NAES of Ukraine has created valuable works the focus of which lies on a broad spectrum of individual professional development problems. For instance, it is the monograph 'Philosophy of pedagogical activity' by the academician I. Ziaziun (Ziaziun, 2008). Considering individual freedom in the space of pedagogical actions, elaborating techniques and technologies of individual freedom development in the educational process, substantiating predictions on education systems evolution, personal and professional ontogenesis in the context of andragogy, the prominent Ukrainian philosopher and educator objectively referred to synergetic pedagogy parameters, in particular to the necessary and accidental.

The importance of such an approach is stressed in the works of T.V. Novatskyi and foreign members of the NAES of Ukraine Z. Viatrovskyi, S. Kviatkovkyi, G. Bednarchyk, F. Shlozek. These very aspects of professionalism have to be more deeply investigated by philosophers, educators and economists under the conditions of dynamic changes in the labour market. It is facilitated by the outline of currently important and promising professionalism aspects gradually formed in Ukrainian philosophy, psychology and pedagogy if to take into account the works of the scientific schools of such academicians as S. Maksymenko, of V. Moliako on creativity problems, of $\mathrm{V}$. Kremen on the child-centrism and innovation phenomenon, of I. Ziaziun on the art of teaching, of S. Honcharenko on education fundamentalisation. 
Experience of previous and contemporary generations has proven professional identity and further professional development to serve as a basis of individuals' success in life determining their objective self-esteem. Unprofessionalism in the economic sectors, at different levels of government authorities leads to enormous economic losses and exacerbates the problem of social injustice.

Considering the research findings of the Ukrainian scholars, we have elaborated the recommendations for the state policy on production personnel training at the following levels: nationwide, regional, field and the level of academic research.

\section{CONCLUSIONS}

Changes in vocational training systems in different countries and especially in Ukraine are regular. Here we are referring to systemic changes introduced by the state policy aimed at highly qualified workers' training. Such an approach is directed towards a gradual reduction of imbalance between white-collar and blue-collar workers worriedly mentioned in the works by D. Bell and other foreign scholars (Bell, 2012). According to the official statistics, such a disproportion in Ukraine is considerably increasing. Its negative foundation is in the inverted pyramid (as it is known, in the advanced European countries the percentage of school graduates receiving academic education is $20-25 \%$ and vocational training - 75-80\%).

Thus, socioeconomic transformations and the related unemployment phenomenon, Ukraine and other countries European integration focus, transformations in education systems, substantiation of Ukrainian labour potential development strategies - these are just some conditions objectively determining the need for understanding and analysis of the education system and labour market interaction.

European integration processes penetrate all spheres of our society. In terms of education, they are dynamic and rich in content, have wide possibilities and topnotch mechanisms for a rapid development in the age of information technologies. Facilitation of Ukraine becoming a Member State of the Pan-European Education and Science Space requires closer attention to nurturing both a patriot and a European. It brings about the objective need to substantiate a conceptual basis of continuous individual professional development.

The European Strategy "Europe 2020" is directed towards the human capital theory implementation under the conditions of information and of course digital society. As noted by José Manuel Barroso, the President of the European Commission, this Strategy "concerns not only the EU Member States - it may also serve as a guide for candidate and neighbouring countries formulating their policies based on the aims and objectives proposed by Europe. It is important for Ukraine as well with its focus on the EU integration and commitment to meet and act according to the rules accepted in the European society" (Oliinyk, 2015: p. 207). Human capital development is a strategic objective of Ukraine's socioeconomic advancement. Its achievement is consistently connected with forward-looking vocational education development. 


\section{REFERENCES}

Ball, H. O., Zlyvkov, V. L., Kopylov, S. O. ta in. (2014). Stanovlennia identychnosti fakhivtsia: monohrafiia [Creation of a specialist's identity: monograph]. Kyiv - Kirovohrad: Iteks LTD. (in Ukrainian)

Bell, D. (2012). Nastannia postindustrialnoho suspilstva [The onset of a post-industrial society]. Filosofiia: khrestomatiia (vid vytokiv do sohodennia): navchalnyi. posibnyk. $2 \mathrm{vyd}$. [Philosophy: the textbook (from the origins to the present): learning manual. 2nd ed]. Kyiv: Znannia. (in Ukrainian)

Chyzhevskyi, B. H., Holovinov, V. P., Krasniakov, Ye. V., \& Shevchenko, M. M. (2013). Zakonodavstvo Ukrainy u sferi osvity ta profesiinoho navchannia (Verkhovna Rada Ukrainy, Komitet $z$ pytan nauky i osvity) [Legislation of Ukraine in the field of education and vocational training (Verkhovna Rada of Ukraine, Committee on Science and Education)]. Kyiv: Parlamentske vydavnytstvo. (in Ukrainian)

Halchynskyi, A. (2006). Hlobalni transformatsii: kontseptualni alternatyvy. Metodolohichni aspekty: Naukove vydannia [Global transformations: conceptual alternatives. Methodological aspects]. Kyiv: Lybid. (in Ukrainian)

Karamushka, L., \& Tkalych, M. (2009). Samoaktualizatsiia menedzheriv u profesiino-upravlinskii diialnosti (na materiali diialnosti komertsiinykh orhanizatsii): monohrafiia [Self-actualization of managers in professional management (on the basis of the activities of commercial organizations): monograph]. Kyiv - Zaporizhzhia: "Prosvita". (in Ukrainian)

Kostyuk, G. S. (1988). Izbrannye psikhologicheskie trudy [Selected psychological works]. Moskva: Pedagogika. (in Russian)

Kremen, V. (2015). Chomu my bidni, yakshcho taki osvicheni? [Why are we poor, if so educated?]. Dzerkalo tyzhnia, 6 (202), 21-27 liutoho 2015, 13.

Kremen, V. H. (2010). Filosofiia natsionalnoi idei. Liudyna. Osvita. Sotsium [Philosophy of the national idea. Man. Education. Socium]. Kyiv: Diploma. (in Ukrainian)

Kremen, V. H. (ed.) (2008). Entsyklopediia osvity [Encyclopedia of Education]. Kyiv: Yurinkom Inter. (in Ukrainian)

Kremen, V. H. (ed.) (2016). Natsionalna dopovid pro stan i perspektyvy rozvytku osvity $v$ Ukraini [National report on the state and prospects of education in Ukraine]. Kyiv: Pedahohichna dumka. (in Ukrainian)

Maslou, A. (1999). Novye rubezhi chelovecheskoy prirody; Perevod s angl. [New frontiers of human nature; translation from English]. Moskva: Smysl. (in Russian)

Nychkalo, N. (2012). Teoriia liudskoho kapitalu i pedahohika pratsi. Kszta cenie zawodowe: pedagogika i psychologia [Theory of human capital and the pedagogy of labor. Knowledge on the subject: pedagogy and psychology]. Profesiina osvita: pedahohika i psykholohiia: pol.-ukr., ukr.-pol. shchorichnyk, XIV, 25-36.

Nychkalo, N. (2016). Nezlamnist ukrainskoi proftekhosvity [Inevitability of Ukrainian vocational education]. Profesiino-tekhnichna osvita. 4 (73), 2-4.

Nychkalo, N. H. (ed.) (2004). Proftekhosvita Ukrainy: XX stolittia: entsyklopedychne vydannia [Professional Education of Ukraine: XX Century: Encyclopedic Edition]. Kyiv: “ArtEk”. (in Ukrainian)

Oliinyk, T. I., Horokh, O. V., \& Hrubnik, O. Iu. (2015). Stratehiia “Ievropa 2020”. Spivrobitnytstvo - zaporuka staloho rozvytku Ukrainy ta Yevropy [Europe 2020 Strategy. Cooperation - the key to sustainable development of Ukraine and Europe]. Visnyk KhNAU. Seriia: Ekonomichni nauky, 2, 206-211. 
II Vseukrainskyi zizd pratsivnykiv osvity (2002) [II All-Ukrainian Congress of Education Workers]. Kyiv.

Shynkaruk, V. I. (ed.), (2002). Filosofskyi entsyklopedychnyi slovnyk [Philosophical Encyclopedic Dictionary]. Kyiv: Abrys. (in Ukrainian)

Stouns, E. (1984). Psikhopedagogika. Psikhologicheskaya teoriya i praktika: obucheniya; Perevod s angl. [Psychopedagogy. Psychological theory and practice: learning; translation from English]. Moskva: Pedagogika. (in Russian)

Ziaziun, I. (2008). Filosofiia pedahohichnoi dii [Philosophy of pedagogical action]. Cherkasy: vyd. vid ChNU imeni Bohdana Khmelnytskoho. (in Ukrainian) 